\title{
Influence of drying methods on cocoa (Theobroma cacao L.): antioxidant activity and presence of ochratoxin $A$
}

\author{
Valterney Lima DEUS ${ }^{1}$, Mariana Barros de CERQUEIRA E SILVA ${ }^{1}$, Leonardo Fonseca MACIEL ${ }^{1,2 *}$, \\ Lucas Caldeirão Rodrigues MIRANDA², Elisa Yoko HIROOKA², Sérgio Eduardo SOARES ${ }^{1}$, \\ Ederlan de Souza FERREIRA ${ }^{1}$, Eliete da Silva BISPO $^{1}$
}

\begin{abstract}
This work aimed to evaluate the performance of different drying methods in the development of phenolic compounds, methylxanthines, and antioxidant activity in cocoa bean and to evaluate the presence of ochratoxin A (OTA). Antioxidant activity was determined using DPPH, FRAP, ORAC and $\beta$-carotene-linoleic acid assays. Phenolic compounds and methylxanthines were determined using high-performance liquid chromatography with an ultraviolet detector (HPLC-UV). OTA was determined by ultra-performance liquid chromatography with fluorescence detection (UPLC-FLR). It was found that during cocoa drying, there was a reduction in antioxidant activity with reduced phenolic compound content $\left(0.04 \mathrm{mg} \cdot \mathrm{g}^{-1}\right.$ of catechin before drying to $0.02 \mathrm{mg} \cdot \mathrm{g}^{-1}$ after drying) and reduced methylxanthines (19.44 mg. $\mathrm{g}^{-1}$ of theobromine before drying to $11.71 \mathrm{mg} \cdot \mathrm{g}^{-1}$ after drying). Only one sample showed contamination by OTA $\left(7.1 \mu \mathrm{g} \cdot \mathrm{kg}^{-1}\right)$. The traditional drying method showed the highest conservation of antioxidant activity and methylxanthine and phenolic compound content.
\end{abstract}

Keywords: catechin; epicatechin; caffeine; theobromine; mycotoxin.

Practical Application: Evaluation of the efficiency of different methods of drying cocoa.

\section{Introduction}

Cocoa has a characteristic and complex chemical composition. Chocolate is its principal product and is generally consumed for its sensory qualities. It has been recognized however, as a source of bioactive compounds with potential health benefits.

In cocoa preprocessing after harvest, cocoa beans are fermented and then dried to reduce moisture content and water activity. The drying process interferes with biochemical reactions initiated during fermentation, leading to a reduction in the bitterness, astringency, and acidity of cocoa beans. Darkening cotyledons contribute to the formation of precursors for desirable flavor in the final product (Beckett, 2009).

Drying may be carried out naturally using solar or artificial energy in greenhouses. Drying conditions can promote reactions that form new compounds that are responsible for the development of the distinctive chocolate color. There is evidence that during drying, there is a reduction in polyphenol content due to enzymatic browning caused by a polyphenoloxidase reaction, followed by non-enzymatic browning resulting from the quinone polymerization due to the accumulation of insoluble compounds.

Drying is also responsible for reducing the acidity of cocoa beans and should be conducted in such a way as to obtain a moisture content of approximately 7\%. Excessive drying can make the shell brittle, whereas excess moisture favors fungal development. The number of phenolic compounds present in cocoa beans and chocolate depends not only on genetic characteristics but also on other factors, such as climate, soil properties, growing region, and cocoa processing (Jalil \& Ismail, 2008). Kyi et al. (2005) determined the oxidation reaction kinetics of polyphenols in cocoa beans during drying at temperatures varying between 40 and $60^{\circ} \mathrm{C}$ and moisture content between 50 and $80 \%$. The authors found that the higher the temperature and moisture content, the higher the oxidation of polyphenols in cocoa.

Ochratoxins are secondary metabolites produced by fungi from the genera Aspergillus and Penicillium, usually present in cereals, coffee, grapes, peppers, and cocoa (Amézqueta et al., 2009; Duarte et al., 2010). Ochratoxin A (OTA) in tropical climates is produced by Aspergillus ochraceus and Aspergillus from the Nigri group, which includes Aspergillus carbonarius (Kara et al., 2015).

OTA is known for its carcinogenic, nephrotoxic, teratogenic, genotoxic, and immunotoxic properties in animal cells (International Agency for Research on Cancer, 1993). Humans are more sensitive to its nephrotoxic effects. Classified as Group 2B (possible human carcinogen) by the International Agency for Research on Cancer (1993), OTA has been found in cocoa powder coming from the Ivory Coast, Guinea, Nigeria, and Cameroon (Serra Bonvehí,

${ }^{1}$ Departamento de Análises Bromatológicas, Faculdade de Farmácia, Universidade Federal da Bahia - UFBA, Salvador, BA, Brasil

${ }^{2}$ Departamento de Ciência e Tecnologia de Alimentos, Universidade Estadual de Londrina - UEL, Londrina, PR, Brasil

${ }^{*}$ Corresponding author: Ifmaciel@ufba.br 
2004), in chocolates in Italian stores (Tafuri et al., 2004), and in Brazilian cocoa beans (Copetti et al., 2010).

Data on the presence of OTA in cocoa and chocolate are limited, especially in terms of pre-processing steps. The critical step for cocoa contamination by OTA and the conditions that stimulate or suppress the production of this toxin have not been established.

In this context, this study aimed to evaluate antioxidant activity, determine phenolic compounds and methylxanthine content, and determine the presence of ochratoxin A in cocoa dried using different methods.

\section{Materials and methods}

\subsection{Materials}

It was used a blend of cocoa fruits (Theobroma cacao L.) Forastero from a farm in the south of Bahia located in the

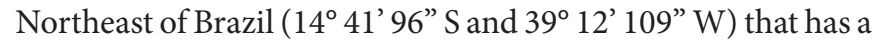
tropical climate. The seeds were derived from natural fermentation processes before and after drying, were used.

\subsection{Methods}

The samples were dried using four dryer types:

- Dryer with stainless steel platform and plastic roof with UV protection (DP);

- Artificial dryer, using wooden platform with artificial heat source, through forced and heated air circulation with electric resistance and temperature controlled by thermostat at $60^{\circ} \mathrm{C}(\mathrm{AD})$;

- Traditional dryer in barge with wooden platform and drying by direct sun light (TD);

- Mixed dryer with stainless steel platform and mobile plastic roof with UV protection for drying coverage and exposure to sun light (MD).

The drying time was seven days following the procedures adopted for the farm. Three samples from each dryer type were analyzed before and after the drying process. Cocoa beans were lyophilized before defatting. All analyses were performed in triplicate. The temperature in the dryers was monitored with thermometer.

\section{Moisture}

Moisture content was determined gravimetrically using an oven with circulating air at $105^{\circ} \mathrm{C}$ up to constant weight according to AOAC guidelines (Association of Official Analytical Chemists, 1995).

\section{Phenolic compounds}

Samples were previously defatted three times with petroleum ether in a shaker for 30 minutes. Using defatted samples, the procedure described by Larrauri et al. (1997) was followed. One gram of sample was weighed in an Erlenmeyer flask,
$40 \mathrm{~mL}$ of methanol $50 \%(\mathrm{v} / \mathrm{v})$ was added, and the mixture was homogenized and set aside for 60 minutes at room temperature. After this process, the contents were centrifuged at $250 \mathrm{~Hz}$ for 15 minutes, and the supernatant was transferred to a $100 \mathrm{~mL}$ volumetric flask. To the first extraction residue, $40 \mathrm{~mL}$ of $70 \%$ acetone $(\mathrm{v} / \mathrm{v})$ was added; then, it was homogenized and set aside for 60 minutes at room temperature. The contents were centrifuged again at $250 \mathrm{~Hz}$ for 15 minutes, and the supernatant was transferred to a vial containing the first supernatant and diluted to $100 \mathrm{ml}$ with distilled water.

\section{Antioxidant activity}

\section{DPPH (2,2-diphenyl-1-picrylhydrazyl) method}

The DPPH method outlined by Brand-Williams et al. (1995) and modified by Sánchez-Moreno et al. (1999) was used. To evaluate antioxidant activity, $0.1 \mathrm{~mL}$ of extract obtained at a concentration of $10 \mathrm{mg} \cdot \mathrm{mL}^{-1}$ was subjected, without light, to reaction with $3.9 \mathrm{~mL}$ of the DPPH radical $(0.06 \mathrm{mM})$ and homogenized in a shaker tube. The radical reduction was measured by absorbance continuously monitored at $515 \mathrm{~nm}$ against the reduction in the blank using a UV spectrophotometer for $30 \mathrm{~min}$ at room temperature in the dark. The values were calculated using a linear regression, and the results are presented as averages. A reduction of absorbance in the sample $\left(\mathrm{A}_{\mathrm{smp}}\right)$ was calculated in comparison with a reduction of control absorbance $\left(A_{d}\right)$ and expressed as a free radical seizure percentage (\% FRS) according to the Equation 1 below:

$\% F R S=\left(\left(A_{d}-A_{\text {smp }}\right) / A_{d}\right) \times 100$

\section{Ferric Reducing Antioxidant Power (FRAP)}

The FRAP method was used to evaluate reduction power based on the method described by Pulido et al. (2000) with some modifications. FRAP reagent was prepared as follows: $2.5 \mathrm{~mL}$ of TPTZ (2,4,6-Tripyridyl-s-Triazine) solution ( $10 \mathrm{mM})$ in $40 \mathrm{mM} \mathrm{HCl}$ added to $2.5 \mathrm{~mL}$ of $\mathrm{FeCl}_{3} \cdot 6 \mathrm{H}_{2} \mathrm{O}$ and $25 \mathrm{~mL}$ of acetate buffer $(0.3 \mathrm{mM} \mathrm{pH} 3.6)$. The solution was incubated at $37^{\circ} \mathrm{C}$ for 30 minutes. For antioxidant activity evaluation, $2.7 \mathrm{~mL}$ of the FRAP reagent was mixed with $270 \mu \mathrm{L}$ of distilled water and $90 \mu \mathrm{L}$ of sample or standard. Samples and standards were homogenized and incubated at $37^{\circ} \mathrm{C}$ for 30 minutes, and the reading was performed at $595 \mathrm{~nm}$ on the spectrophotometer. Ferrous sulfate solution was used as a standard. Results are expressed as $\mu \mathrm{M}$ ferrous sulfate. $\mathrm{g}^{-1}$ of the sample.

\section{Oxygen Radical Absorbance Capacity (ORAC)}

An ORAC assay was carried out according to the method described in Prior et al. (2005). The fluorescein and AAPH [2,2'-azobis (2-methypropionamidine) dihydrocholoride] solutions and Trolox standard were prepared on the day of analysis. A microplate reader was used (absorbance and fluorescence) with 96-well plates. Analysis was performed in phosphate buffer $\left(\mathrm{pH} \mathrm{7.4)}\right.$ at $37^{\circ} \mathrm{C}$. Fluorescein was used as the substrate. The protective antioxidant effect was verified by calculating the area under the curve (AUC) of the sample fluorescence when undergoing oxidative damage versus time compared to the blank. Fluorescence conditions 
were as follows: excitation at $485 \mathrm{~nm}$ and emission at $520 \mathrm{~nm}$. Results are expressed as $\mathrm{mM}$ of Trolox equivalent. $\mathrm{g}^{-1}$ of sample.

$\beta$-carotene-linoleic acid system

A $\beta$-carotene linoleic acid assay was carried out according to the method of Duarte-Almeida et al. (2006). To prepare the reactive mixture, $20 \mu \mathrm{L}$ of linoleic acid, $200 \mathrm{mg}$ of Tween $40,25 \mu \mathrm{L}$ of $\beta$-carotene solution ( $2.0 \mathrm{mg} \cdot \mathrm{mL}^{-1}$ in chloroform) and $500 \mu \mathrm{L}$ of chloroform were added to an Erlenmeyer flask. Subsequently, the mixture was subjected to complete evaporation of the chloroform, and $25 \mathrm{~mL}$ of water saturated with oxygen was added to the mixture with the chloroform evaporated. To the test tube, $250 \mu \mathrm{L}$ of reaction mixture and $10 \mu \mathrm{L}$ of extracts or methanol (control sample) were added. The tubes were heated at $50{ }^{\circ} \mathrm{C}$ for approximately 2 minutes in order to accelerate oxidation reactions and initiate $\beta$-carotene bleaching after cooling. Readings were taken for initial absorbance and final absorbance (after two hours) in a spectrophotometer at $470 \mathrm{~nm}$. The sample absorbance decrease (SAD) and the control absorbance (Ca) were used to yield the percentage of oxidation inhibition (\% I) by the Equation 2:

$\% I=((C a-S A D) / C a) \times 100$

\section{Monomeric phenols and methylxanthine determination}

Ten microliters of each sample were analyzed with a high-performance liquid chromatography (HPLC) system (Perkin Elmer Model Flexar) equipped with an injector Flow VI and a C-18 column $(250 \times 4.6$ millimeters / $5 \mu)$. The column was maintained at $30{ }^{\circ} \mathrm{C}$, and the wavelength used for detection was $280 \mathrm{~nm}$. The standards (Sigma Chemical Co., USA) used for this study were phenolic compounds (Catechin and Epicatechin) and methylxanthines (Theobromine and Caffeine). The standard solutions were prepared in methanol, and calibration curves were obtained from five injections in duplicates of five concentrations. Elution was carried out along the gradient as shown in Table 1, wherein the mobile phases used were water acidified with $1 \%$ phosphoric acid (A) and methanol (B). The total run time was 75 minutes.

\section{Determination of ochratoxin A}

An Acquity ultra-performance liquid chromatography (UPLC) system (Waters ${ }^{\circledR}$, USA) was used with fluorescence detection at $335 \mathrm{~nm}$ excitation and $478 \mathrm{~nm}$ emission for detection of ochratoxin

Table 1. Gradient utilized for separating phenolic compounds and methylxanthines by HPLC.

\begin{tabular}{cccc}
\hline $\begin{array}{c}\text { Time } \\
(\min )\end{array}$ & $\begin{array}{c}\text { Flow } \\
\left.\left(\mathrm{mL}_{\mathrm{min}}\right)^{-1}\right)\end{array}$ & $\begin{array}{c}\text { Mobile phases } \\
\mathrm{A}(\%)\end{array}$ & $\begin{array}{c}\text { Mobile phases } \\
\mathrm{B}(\%)\end{array}$ \\
\hline 7.0 & 0.6 & 100 & 0 \\
10 & 0.6 & 90 & 10 \\
15 & 0.6 & 80 & 20 \\
20 & 0.6 & 75 & 25 \\
30 & 0.6 & 50 & 50 \\
45 & 0.6 & 20 & 80 \\
55 & 0.6 & 50 & 50 \\
75 & 0.6 & 100 & 0 \\
\hline
\end{tabular}

A. The system consists of a temperature-controlled auto sampler set at $10^{\circ} \mathrm{C}$, a binary pump, oven temperature controlled at $40^{\circ} \mathrm{C}$ and an online degassing system. An Ethylene Bridged Hybrid $\left(\mathrm{BEH}\right.$, Waters $\left.{ }^{\circledR}\right)$ column of $10 \mathrm{~cm}$ with a portion of $1.7 \mu \mathrm{M}$ was used. The mobile phase consisted of water acidified with phosphoric acid $\left(\mathrm{H}_{3} \mathrm{PO}_{4}\right) \mathrm{pH} 2$ : acetonitrile $\left(40: 60 \mathrm{v}^{-1}\right)$, isocratic run, with a $3 \mu \mathrm{L}$ injection volume and flow of $0.3 \mathrm{ml} . \mathrm{min}^{-1}$.

\section{Statistical analyses}

The results were statistically analyzed using univariate analysis of variance (ANOVA) and Tukey's mean test $(\mathrm{p}<0.05)$ using SAS version 6.11.

\section{Results and discussion}

After fermentation, $52.18 \%$ of the cocoa bean total weight was moisture. The sample showing the lowest moisture content after drying was the sample subjected to the oven drying process (6.90\%). The next lowest moisture content was found in the sample subjected to the traditional drying method $(7.76 \%)$, followed by the samples dried using the stainless steel dryer with plastic roof, with UV protection (8.08\%) and without UV protection (8.03\%).

We may be able to explain these results owing to temperature differences experienced by the cocoa beans from the different drying methods. Artificial drying in the oven produced the highest temperature, followed by drying with direct sun light. Dryers with plastic roofs had the mildest temperatures. Were monitored the temperatures with thermometer and the drying that depended on solar light varied quite the temperatures but never exceeding $60{ }^{\circ} \mathrm{C}$, temperature of the oven. All samples were considered acceptable for dry cocoa beans. Drying should be carried out until cocoa beans reach 7 to $8 \%$ water content, which requires 2-10 days depending on the method used or climatic conditions.

Figure 1 shows the chromatogram of phenolic compounds and methylxanthines standards, theobromine, $(+)$ - catechin, caffeine, and (-) - epicatechin, respectively, and Figure 2 shows the OTA A standard chromatogram.

The chromatograms showed good resolution without the presence of interference peaks. The retention times for the analytes in the samples were similar to the peaks for the standard solution. The identification of the interesting analytes occurred by analysis of retention time compared to the respective standards and spectra.

Phenolic composition and methylxanthine composition in dry and defatted cocoa extracts before and after drying and presence of OTA ( $n$ of the sample, positive sample, and range) are shown on Table 2.

Results showed higher epicatechin content than catechin and higher theobromine content than caffeine, as was also reported by Leite et al. (2013) who studied cocoa mass and Carrillo et al. (2014) who studied sun-dried cocoa beans.

Cocoa beans prior to drying showed higher theobromine $\left(19.44 \pm 0.34 \mathrm{mg} \cdot \mathrm{g}^{-1}\right)$ and caffeine $\left(2.74 \pm 0.03 \mathrm{mg}^{\circ} \mathrm{g}^{-1}\right)$ content 


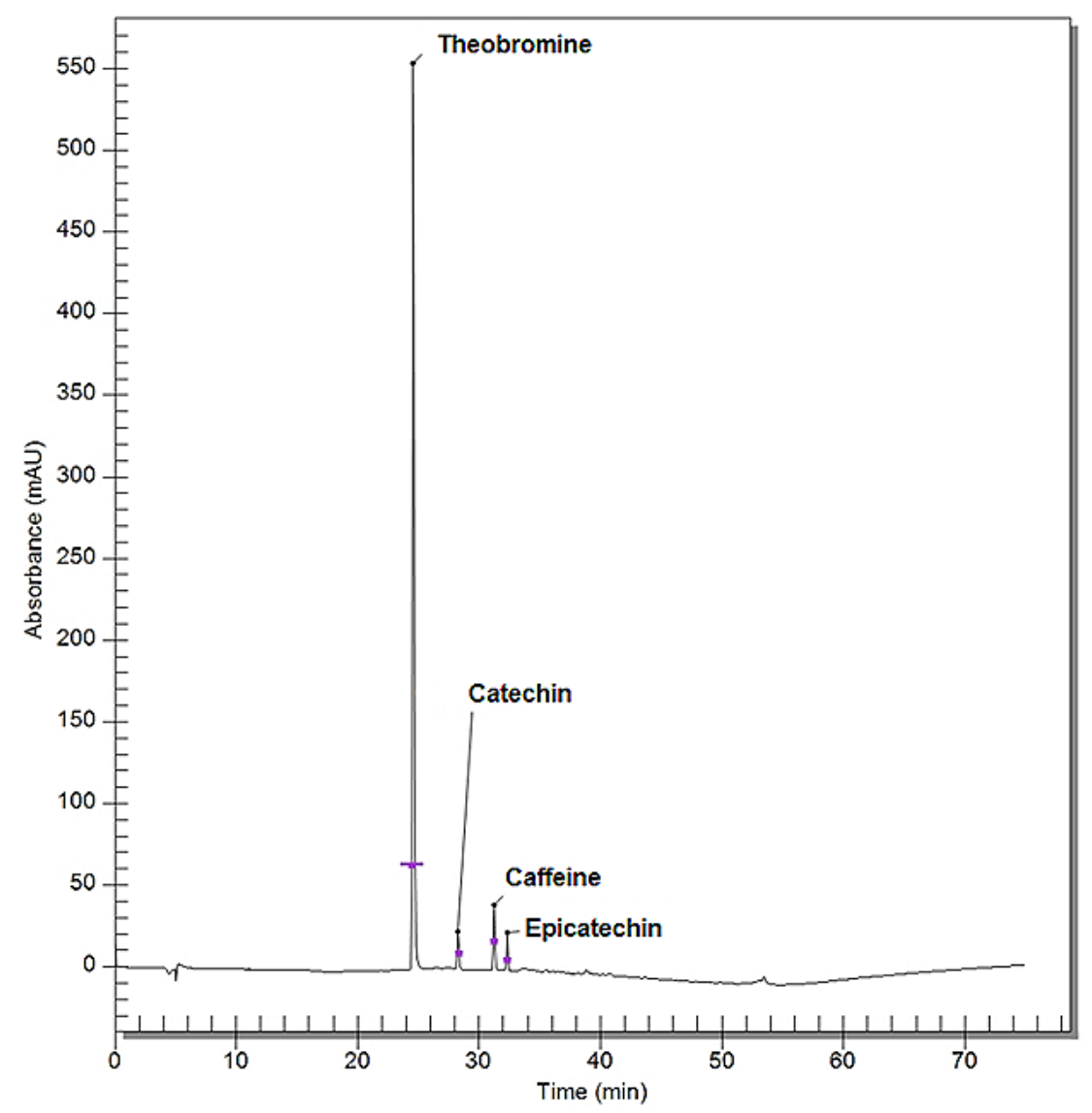

Figure 1. Phenolic compounds and methylxanthine sample chromatogram.

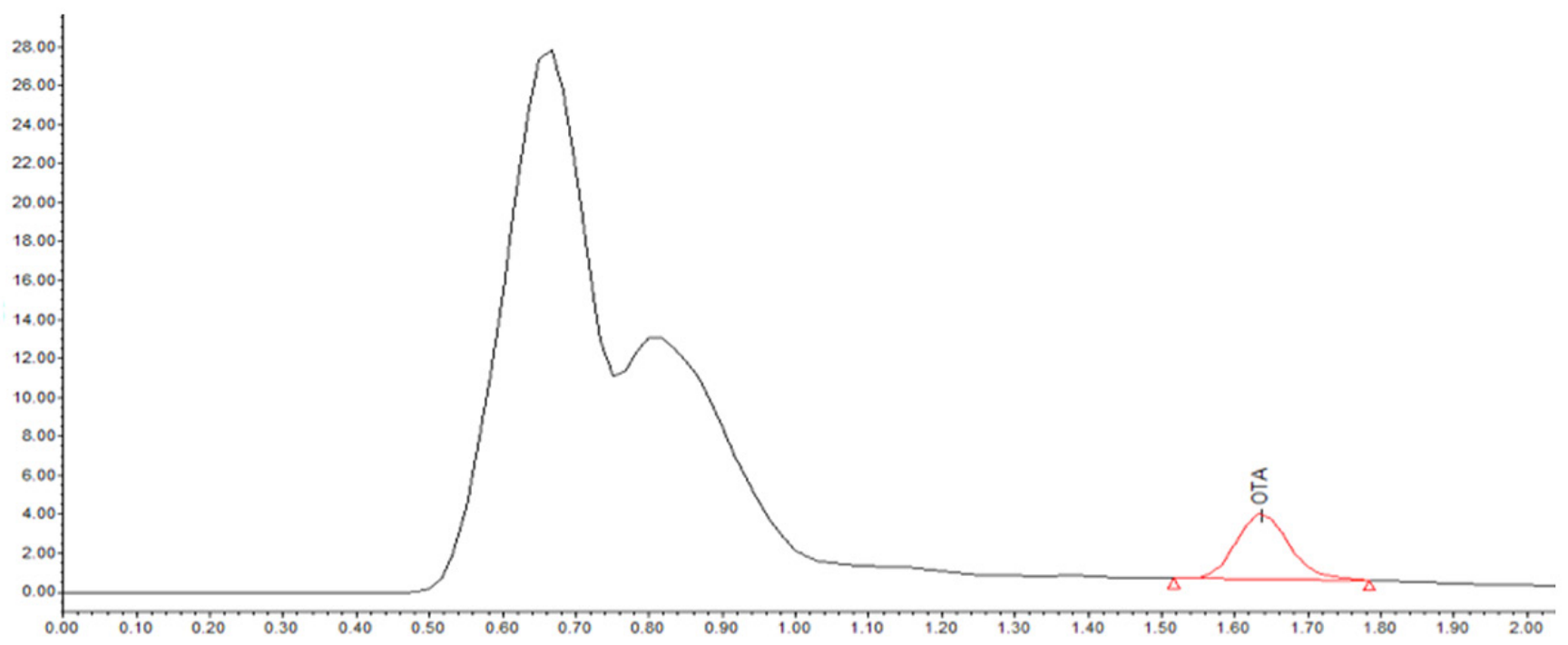

Figure 2. Ochratoxin A sample chromatogram.

than cocoa beans after drying, regardless of the dryer used, confirming that there is a methylxanthine content reduction during drying. The findings of this study were similar to those of Belscak et al. (2009), who found theobromine $\left(16 \mathrm{mg} \cdot \mathrm{g}^{-1}\right)$ and caffeine $\left(2 \mathrm{mg} \cdot \mathrm{g}^{-1}\right)$ in the dry cocoa analysis.

Theobromine levels were higher than those for caffeine in all samples. This fact is very important from a health perspective because caffeine acts as a stimulant and vasoconstrictor, whereas theobromine acts as a vasodilator and lowers blood pressure. Furthermore, theobromine acts as a muscle relaxant and diuretic (Van den Bogaard et al., 2010).

The traditional drying method was the one that most retained the methylxanthine content in dry seeds, showing that these chemical compounds are susceptible to degradation due 
Drying methods on cocoa: antioxidant activity and presence of ochratoxin A

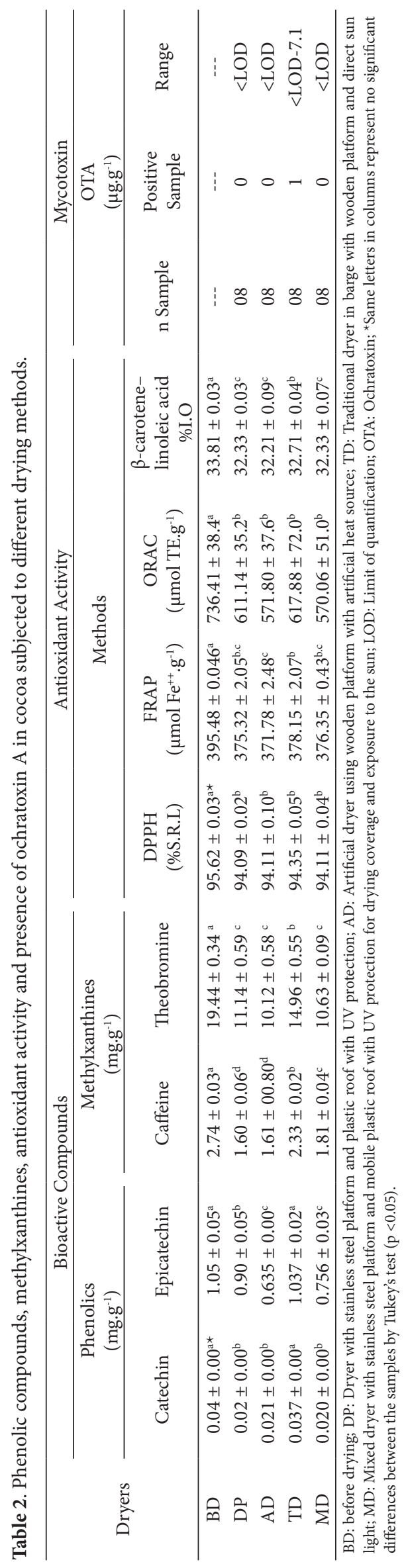


to temperature variation. Changes may occur in polyphenol and methylxanthine content during cocoa and chocolate processing, particularly when high temperatures are reached (Kyi et al., 2005). Drying conditions can promote oxidative reactions that contribute to reactions that form new compounds, resulting in a decrease in sensory performance and the development of the "brown" color of chocolate. Depending on the adopted process, there is a reduction of methylxanthine and phenolic compounds during drying (Brito et al., 2000; Payne et al., 2010).

Epicatechin content was higher than catechin in all examined extracts. The values found in this study were similar to those of Belscak et al. (2009), who found $1.06 \pm 0.16 \mathrm{mg} \mathrm{g}^{-1}$ of epicatechin and $0.38 \pm 0.10 \mathrm{mg} \cdot \mathrm{g}^{-1}$ of catechin in cocoa mass.

Among cocoa bean drying methods, we found traditional drying to be the one that best retained phenolic compound content, showing no difference at $0.05 \%$ between epicatechin and catechin content before and after drying.

With the other drying methods, there was a reduction in phenolic compound content in the cocoa beans, especially when artificially oven-dried. These values were consistent with those found by Belscak et al. (2009) in cocoa powder extracts.

In traditional drying, with barge and direct sunlight, cocoa beans are exposed to heat, but the maximum temperature is cooler compared to covered and artificial dryers. In sun-dried samples, it is likely that cocoa beans have suffered less structural changes, with a limited effect on chemical and enzymatic reactions.

The tendency for reduction of monomers during drying was also observed in other epicatechin studies, such as those conducted by Kim \& Keeney (1984), Kealey et al. (1998) and Camu et al. (2008).

In a study by Di Mattia et al. (2012), drying time and temperature affected epicatechin and catechin content. Theauthors concluded that this phenomenon may be due to rapid drying initially favoring condensation reactions. Other studies have shown that the drying rate is the most important factor in the preservation of a plant's phenolic compound content (Mrkic et al., 2006).

There is little information in the literature regarding fermentation and drying effects on the procyanidin profile, on the polymerization of monomers to oligomers and polymers, and on some functional properties, such as antioxidant activity reduction (Aikpokpodion \& Dongo, 2010). However, the health aspects of these compounds should be considered because monomeric phenolic compounds are absorbed and utilized by the human body as exogenous antioxidants (Richelle et al., 1999; Holt et al., 2002).

A reduction in antioxidant activity was observed in cocoa beans after drying in all analysis methods. These results confirm those found by Efraim et al. (2010), who showed that there was antioxidant activity loss during cocoa bean drying.

Based on the DPPH (hydrazyl 2.2-diphenyl-1-picryl) method, which is an indirect method, there was a decrease in antioxidant activity in the sample after drying. There was no significant difference in dry cocoa bean antioxidant activity according to drying method, ranging from $94.09 \%$ of dry sample free radical scavenging (FRS) in the stainless steel dryer with plastic roof and UV protection to $94.35 \%$ of dry sample FRS using the traditional method. The value found for antioxidant activity in dried samples was similar to what Kowalska \& Sidorczuk (2007) found when dry cocoa beans from the Ivory Coast were analyzed.

In the analysis using the FRAP method, in which the $\mathrm{Fe}^{2+}$ - TPTZ complex formation was spectrophotometrically monitored, $395.48 \pm 0.46 \mu \mathrm{mol} \mathrm{Fe}{ }^{++} \cdot \mathrm{g}^{-1}$ was detected in the cocoa beans prior to drying. This antioxidant activity was reduced in all samples after drying, regardless of the methodology adopted. It was found that the sample that underwent the drying process in an oven suffered the most significant reduction in antioxidant activity, $371.78 \pm 2.48 \mu \mathrm{mol} \mathrm{Fe}{ }^{++} \cdot \mathrm{g}^{-1}$, and the sample with the smallest reduction in antioxidant activity was the one dried using direct sun light, $378.15 \pm 2.0707 \mu \mathrm{mol} \mathrm{Fe} \mathrm{F}^{++} . \mathrm{g}^{1}$. Analysis by the FRAP method has the limitation that the system should be aqueous (Moon \& Shibamoto, 2009).

In ORAC analysis, cocoa bean scavenging ability was checked in conjunction with a peroxyl radical induced by AAPH at $37^{\circ} \mathrm{C}$ where the peroxyl radical reacted with fluorescein, forming a non-fluorescent product (Prior et al., 2005). Extracts rapidly reacted with radicals, donating hydrogen atoms and inhibiting loss of fluorescence intensity, forming a competition system. Fluorescein has high photostability and does not interact with antioxidants (Prior et al., 2005).

This analysis showed that there was no significant difference between types of dryers in conserving antioxidant activity, ranging from $617.88 \pm 72.0$ for the wooden dryer with direct sun drying (Traditional) to $570.06 \pm 51.0$ in the stainless steel dryer with plastic roof and UV protection. In this method, antioxidant activity reductions during cocoa drying were confirmed, with significantly lower values found in all cocoa beans after drying compared to the values recorded in the sample prior to drying, $736.41 \pm 38.4$.

The results of this study resemble those of Crozier et al. (2011) who analyzed cocoa mass, and antioxidant activity measured with the ORAC method was $634 \pm 33 \mu$ MTE. $g^{-1}$. Similar values were found by $\mathrm{Gu}$ et al. (2006), ranging from 709 to $899 \mu \mathrm{MTE} . \mathrm{g}^{-1}$, and by Miller et al. (2006), ranging from 720 to $875 \mu \mathrm{MTE}^{-1}$, in cocoa mass analysis.

In the $\beta$-carotene-linoleic acid method, cocoa bean extracts dried using the traditional method were the most protected from oxidation emulsion, $32.71 \pm 0.04 \%$. Samples artificially dried in an oven were the least likely to have contributed to system oxidation, and had lower antioxidant activity, $32.21 \pm 0.09 \%$. Extracts showed that they had compounds capable of interacting at the water/lipid interface where the oxidative process begins.

Othman et al. (2007) compared the antioxidant activity of cocoa beans from various producing countries and obtained values ranging from $26.1 \pm 1.8 \%$ and $74.1 \pm 2.5 \%$ for alcoholic extracts (ethanol). Thus, the results were consistent with those found in this study.

The study results demonstrate that antioxidant activity is not only related to monomeric phenol concentration, given that traditionally dried extract samples showed no significant 
differences with other samples in terms of catechin and epicatechin concentrations before drying. However, with all methods, cocoa bean antioxidant activity before drying was higher compared to that in dried samples.

Of the 32 samples examined, only one showed natural contamination by ochratoxin A $\left(7.1 \mu \mathrm{g} \cdot \mathrm{kg}^{-1}\right)$. The European Community in the EC Regulation No. 1881/2006 of the Commission of 19/Dec/2006 does not establish OTA limits for cocoa. The National Health Surveillance Agency of Brazil (ANVISA) establishes a value of $10 \mu \mathrm{g} \cdot \mathrm{kg}^{-1}$ of OTA in cocoa. The only positive sample showed a value lower than that established by ANVISA.

\section{Conclusion}

During cocoa drying, there is a reduction in antioxidant properties. This loss is not only related to phenolic compounds and methylxanthine content but is also related to interactions between bioactive compounds, thus decreasing their properties. The traditional drying method showed the best retention of cocoa antioxidant activity, possibly due to it being a slower drying method that uses milder temperatures. As only one sample of cocoa had OTA contents, it was not possible to infer the influence of the dryers on the occurrence of this mycotoxin.

\section{Acknowledgements}

The authors gratefully acknowledge the financial support of the National Counsel of Technological and Scientific Development $(\mathrm{CNPq})$ strategic research initiative under the auspices of the Brazilian Ministry of Education, project number 477403/2012-3.

\section{References}

Aikpokpodion, P. E., \& Dongo, L. N. (2010). Effect of fermentation intensity on polyphenol sand antioxidant capacity of cocoa beans. International Journal of Sustainable Crop Production, 5(4), 66-70.

Amézqueta, S., González-Peñas, E., Murillo-Arbizu, M., \& López de Cerain, A. (2009). Ochratoxin A decontamination: a review. Food Control, 20(4), 326-333. http://dx.doi.org/10.1016/j.foodcont.2008.05.017.

Association of Official Analytical Chemists - AOAC. (1995). Official methods of analysis (16th ed.). Washington: AOAC.

Beckett, S. T. (2009). Industrial chocolate manufacture and use (4th ed., pp. 20-23). London: Chapman \& Hall.

Belscak, A., Komes, D. E., Horzic, D., Ganic, K. K., \& Karlovic, D. (2009). Comparative study of commercial lyavailable cocoa products in terms of their bioactive composition. Faculty of Food Technology and Biotechnology, 42, 707-716.

Brand-Williams, W., Cuvelier, M. E., \& Berset, C. (1995). Use of free radical method to evaluate antioxidant activity. LebensmittelWissenschaft + Technologie, 28(1), 25-30. http://dx.doi.org/10.1016/ S0023-6438(95)80008-5.

Brito, E. S., Pezoa Garcia, N. H., Gallao, M. I., Corelazzo, A. L., Fevereiro, P. S., \& Braga, M. R. (2000). Structural and chemical changes in cocoa (Theobroma cacao L.) during fermentation, drying and roasting. Journal of the Science of Food and Agriculture, 81, 281-288. http://dx.doi.org/10.1002/1097-0010(20010115)81:2<281::AIDJSFA 808 $>3$.0.CO;2-B.
Camu, N., De Winter, T., Addo, S. K., Takrama, J. S., Bernaert, H., \& De Vuyst, L. (2008). Fermentation of cocoa beans: influence of microbial activities and polyphenol concentration son the flavour of chocolate. Journal of the Science of Food and Agriculture, 88(13), 2288-2297. http://dx.doi.org/10.1002/jsfa.3349.

Carrillo, L. C., Londoño-Londoño, J., \& Gil, A. (2014). Comparison of polyphenol, methylxanthines and antioxidant activity in Theobroma cacao beans from different cocoa-growing areas in Colombia. Food Research International, 60, 273-280. http://dx.doi.org/10.1016/j. foodres.2013.06.019.

Copetti, M. V., Pereira, J. L., Iamanaka, B. T., Pitt, J. I., \& Taniwaki, M. H. (2010). Ochratoxigenic fungi and ochratoxin A in cocoa during farm processing. International Journal of Food Microbiology, 143(12), 67-70. http://dx.doi.org/10.1016/j.ijfoodmicro.2010.07.031. PMid:20709419.

Crozier, L. G., Scheuerell, M. D., \& Zabel, R. W. (2011). Using time series analysis to characterize evolutionary and plastic responses to environmental change: a case study of a shift toward earlier migration date in sockeye salmon. American Naturalist, 178(6), 755-773. http:// dx.doi.org/10.1086/662669. PMid:22089870.

Di Mattia, C., Martuscelli, M., Sacchetti, G., Scheirlinck, I., Beheydt, B., Mastrocola, D., \& Pittia, P. (2012). Effect of fermentation and dryingon procyanidins, antiradical activityand reducing properties of cocoa beans. Food and Bioprocess Technology, 6(12), 3420-3432. http://dx.doi.org/10.1007/s11947-012-1028-x.

Duarte, S. C., Pena, A., \& Lino, C. M. (2010). A review on ochratoxin A occurrence and effects of processing of cereal and cereal derived food products. Food Microbiology, 27(2), 187-198. http://dx.doi. org/10.1016/j.fm.2009.11.016. PMid:20141935.

Duarte-Almeida, J. M., Santos, R. J., Genovese, M. I., \& Lajolo, F. M. (2006). avaliação da atividade antioxidante utilizando sistema $\beta$-caroteno/ácido linoléico e método de seqüestro de radicais DPPH'. Food Science and Technology, 26(2), 446-452. http://dx.doi. org/10.1590/S0101-20612006000200031.

Efraim, P., Pezoa-García, N. H., Jardim, D. C. P., Nishikawa, A., Haddad, R., \& Eberlin, M. N. (2010). Influência da fermentação e secagem de amêndoas de cacau no teor de compostos fenólicos e na aceitação sensorial. Food Science and Technology, 30, 142-150. http://dx.doi. org/10.1590/S0101-20612010000500022.

Gu, L., House, S. E., Wu, S., Ou, B., \& Prior, R. L. (2006). Procyanidin and catechin contents and antioxidant capacity of cocoa and chocolate products. Journal of Agricultural and Food Chemistry, 54(11), 40574061. http://dx.doi.org/10.1021/jf060360r. PMid:16719534.

Holt, R. R., Lazarus, S. A., Sullards, M. C., Zhu, Q. Y., Schramm, D. D., Hammerstone, J. F., Fraga, C. G., Schmitz, H. H., \& Keen, C. L. (2002). Procyanidin dimer B2 (epicatechin- (4ß-8)-epicatechin) in human plasma after the consumption of a flavanol-richcocoa. American Journal of Clinical Nutrition, 76(4), 798-804. http://dx.doi. org/10.1093/ajcn/76.4.798. PMid:12324293.

International Agency for Research on Cancer - IARC. (1993). IARC monographs on the evaluation of the carcinogenic risks to humans: some naturally occurring substances: food items and constituents, heterocyclic aromatic amines and mycotoxins (Vol. 56). Lyon: IARC.

Jalil, A. M. M., \& Ismail, A. (2008). Polyphenols in cocoa and cocoa products: is there a link between antioxidant properties and health? Molecules (Basel, Switzerland), 13(9), 2190-2219. http://dx.doi. org/10.3390/molecules13092190. PMid:18830150.

Kara, G. N., Ozbey, F., \& Kabak, B. (2015). Co-occurrence of aflatoxin and ochratoxin A in cereal flours commercialised in Turkey. Food Control, 54, 275-281. http://dx.doi.org/10.1016/j.foodcont.2015.02.014. 
Kealey, K. S., Snyder, R. M., Romaczyk, L. J., Geyer, H. M., Meyers, M. E., Whithcare, E. J., Hammerstone, J. F., \& Schmitz, H. H. (1998). Cocoa components, edible products having enhanced polyphenol content, methods of making same medical uses. Patent Corporation Treaty (PCT) WO 98/09533. USA: Mars Incorporeted.

Kim, H., \& Keeney, P. G. (1984). (-) Epicatechin content in fermented an dun fermented cocoa beans. Journal of Food Science, 49(4), 1090-1092. http://dx.doi.org/10.1111/j.1365-2621.1984.tb10400.x.

Kowalska, J., \& Sidorczuk, A. (2007). Analysis of the effect of technological processing on changes in antioxidant properties of cocoa processed products. Polish Journal of Food and Nutrition Sciences, 75, 95-99.

Kyi, T. M., Wan, W. D., Abu, M., Mohd, S., Abdul, H. K., \& Meor, M. T. (2005). The kinetics of polyphenol degradati on during the drying of Malaysian cocoa beans. International Journal of Food Science \& Technology, 40(3), 323-331. http://dx.doi.org/10.1111/j.13652621.2005.00959.x.

Larrauri, J. A., Rupérez, P., \& Saura-Calixto, F. (1997). Effect of drying temperature on the stability of polyphenols and antioxidant activity of red grape pomace peels. Journal of Agricultural and Food Chemistry, 45(4), 1390-1393. http://dx.doi.org/10.1021/jf960282f.

Leite, P. B., Maciel, L. F., Opretzka, L. C. F., Soares, S. E., \& Bispo, E. S. (2013). Phenolic compounds, methylxanthine sand atioxidant activity in cocoa mas sand chocolates produced from "witch broom disease" resistant and non resistant cocoa cultivars. Ciência e Agrotecnologia, 37(3), 244-250. http://dx.doi.org/10.1590/S1413-70542013000300007.

Miller, K. B., Stuart, D. A., Smith, N. L., Lee, C. Y., Mchale, N. L., Flanagan, J. A., Ou, B., \& Hurst, J. W. (2006). Antioxidant activity and polyphenol and procyanidin contents of selected commercially available cocoa-containing and chocolate products in the United States. Journal of Agricultural and Food Chemistry, 54(11), 4062-4068. http://dx.doi.org/10.1021/jf060290o. PMid:16719535.

Moon, J. K., \& Shibamoto, T. (2009). Antioxidant assays for plant and food components. Journal of Agricultural and Food Chemistry, 57(5), 1655-1666. http://dx.doi.org/10.1021/jf803537k. PMid:19182948.

Mrkìc, V., Cocci, E., Dalla Rosa, M., \& Sacchetti, G. (2006). Influence of drying condition sonbio active compound sand antioxidant activity of dried broccoli (Brassica oleracea L.). Journal of the Science of Food and Agriculture, 86, 1559-1566. http://dx.doi.org/10.1002/jsfa.2554.
Othman, A., Ismail, A., Abdul Ghani, N., \& Adenan, I. (2007). Antioxidant capacity and phenolic content of cocoa beans. Food Chemistry, 100(4), 1523-1530. http://dx.doi.org/10.1016/j.foodchem.2005.12.021. PMid:26065784.

Payne, M. J., Hurst, W. J., Miller, K. B., Rank, C., \& Stuart, D. A. (2010). Impact of fermentation, drying, roasting and Dutch processing on epicatechin and catechin content of cocoa beans and cocoa ingredients. Journal of Agricultural and Food Chemistry, 58(19), 10518-10527. http://dx.doi.org/10.1021/jf102391q. PMid:20843086.

Prior, R. L., Wu, X., \& Schaich, K. (2005). Standardized methods for the determination of antioxidant capacity and phenolics in foods and dietary supplements. Journal of Agricultural and Food Chemistry, 53(10), 4290-4302. http://dx.doi.org/10.1021/jf0502698. PMid:15884874.

Pulido, R., Bravo, L., \& Saura-Calixto, F. (2000). Antioxidant activity of dietary polyphenols as determined by a modified ferric reducing/ antioxidant power assay. Journal of Agricultural and Food Chemistry, 48(8), 3396-3402. http://dx.doi.org/10.1021/jf9913458. PMid:10956123.

Richelle, M., Tavazzi, I., Enslen, M., \& Offord, E. A. (1999). Plasma kinetics in man of epicatechin from black chocolate. European Journal of Clinical Nutrition, 53(1), 22-26. http://dx.doi.org/10.1038/ sj.ejcn.1600673. PMid:10048796.

Sánchez-Moreno, C., A. Larrauri, J., \& Saura-Calixto, F. (1999). Free radical scavenging capacity and inhibition of lipid oxidation of wines, grape juices and related polyphenolic constituents. Food Research International, 32, 407-412. http://dx.doi.org/10.1016/ S0963-9969(99)00097-6.

Serra Bonvehí, J. (2004). Occurrence of ochratoxin A in cocoa products and chocolate. Journal of Agricultural and Food Chemistry, 52(20), 6347-6352. http://dx.doi.org/10.1021/jf040153w. PMid:15453712.

Tafuri, A., Ferracane, R., \& Ritieni, A. (2004). Ochratoxin A in Italian marketed cocoa products. Food Chemistry, 88(4), 487-494. http:// dx.doi.org/10.1016/j.foodchem.2004.01.061.

Van den Bogaard, B., Draijer, R., Westerhof, B. E., van den Meiracker, A. H., van Montfrans, G. A., \& van den Born, B. J. (2010). Effect son peripheral and central blood pressure of cocoa with natural or high dose theobromine: a ramdomized, double-blind crossover trial. Hypertension, 56(5), 839-846. http://dx.doi.org/10.1161/ HYPERTENSIONAHA.110.158139. PMid:20823377. 